\title{
The Politics of Local Government Reform in Northern Ireland
}

Local Government Studies Vol 35 (4): 2009: $435-455$

Colin Knox

Author's details:

Colin Knox

School of Policy Studies

University of Ulster

Newtownabbey

Co Antrim

Northern Ireland

BT37 0QB

Telephone: +44 (0)2890 366667/366378

Email: cg.knox@ulster.ac.uk 


\title{
Title: The Politics of Local Government Reform in Northern Ireland
}

\begin{abstract}
A major review of public administration in Northern Ireland has resulted in proposals for radical reforms in health, education, and local government services. Although originating from the devolved government of 1999, intermittent suspensions resulted in Direct Rule Ministers taking over responsibility for the review. This article traces the influence of a sizeable body of research evidence on the outcomes of the review, specifically controversial reforms to local government, and the significant influence attached to macro political factors in reaching key public policy decisions. It also highlights the asymmetry in power relations between Stormont and local government and how devolution has simply compounded regional centralism in Northern Ireland.
\end{abstract}

\section{Introduction}

Northern Ireland has witnessed its most significant political development for decades. After years of political stalemate, the Northern Ireland Assembly was restored on $8^{\text {th }}$ May 2007 following almost five years in suspension (since October 2002). The (then) Secretary of State for Northern Ireland, Peter Hain, described the establishment of a power-sharing Executive and devolved Assembly as 'the final resolution of what has been, for centuries, the most intractable source of political conflict in Europe' (Hain, 2007: 1). Witnessing the key protagonists, the Democratic Unionist Party (DUP) and Sinn Féin, going into government together, argued Hain, 'makes 'historic' seem like a cliché'. Even allowing for the media hyperbole associated with the occasion, Northern Ireland has entered a new era of political accommodation with huge expectations for 'normal' as opposed to the zero-sum politics of the last 30-odd years. Not surprisingly a backlog of public policy issues awaited the new Executive, key amongst which were: a review of the selective system of secondary level education, the proposed introduction of water charges, and public sector reform.

Since the prorogation of Stormont in 1972, acute political, constitutional and security issues have, for obvious reasons, consumed ministerial energies and the task of running 
their departments has, by default, been left to senior civil servants. Under 'direct rule', British Ministers had no electoral base in Northern Ireland removing any explicit political accountability. These circumstances conferred a special status on officials who wielded virtually unfettered power and controlled significant public resources (Carmichael, 2002). Whilst 'normal' mechanisms of public accountability applied (the fairly remote prospect of appearing in front of Westminster's Public Accounts Committee), Northern Ireland governance was accorded a much lower priority than macro political issues. Given the context of a unique set of political arrangements, by comparison with other parts of the United Kingdom, this paper attempts to do three things. First, it will consider the policy making process in Northern Ireland in the absence of direct ministerial involvement and the influences thereon. Second, using a case study of local government, it will consider whether Northern Ireland has embraced the move towards evidence based policy making heralded by the Labour Government in the rest of the United Kingdom. Third, it will consider the extent to which devolution in Northern Ireland impacts on regional centralism which has characterised central-local government relations since the early 1970s.

\section{Policy Making in Northern Ireland}

But for the short interludes when Northern Ireland had devolved government, policy making has been in the hands of a small civil service élite since 1972. Civil servants, of course, contend that they did not seek such a monopoly on the decision making process but by force of circumstances, visiting ministers were so pre-occupied with more important security matters, public policy matters were left to them. As one observer of the direct rule period put it:

The concern now expressed more frequently than in the past is that the operational impact of the present political circumstances means that senior civil servants are placed in positions of greater influence, either by the effects of direct rule which reduce the involvement of ministers (who cannot be readily available) or the acceptance by senior officials of a higher profile in public (Simpson, 1997: $4)$.

Given the powerful role assumed by civil servants, it is no surprise that some found it difficult to adjust to the accountability demands placed on them by the return of devolved 
government in December 1999 (albeit for intermittent periods thereafter). A leaked memo in 2001 from the (then) Permanent Secretary of Regional Development highlighted resistance to requests from the Assembly's statutory Environment Committee for access to departmental working papers. The Permanent Secretary referred to practice elsewhere in the United Kingdom and 'difficulties' created by 'the lack of the sort of conventions about the roles of Ministers, officials, the Assembly, Committees, etc which have evolved over centuries in Westminster' (Northern Ireland Assembly, Research and Library Services, 2001:15). Members of the Legislative Assembly, in turn, perceived this as civil servants being unwilling to co-operate with elected representatives. Further criticism of civil servants came from Social Democratic and Labour Party (SDLP) leader Mark Durkan who claimed that even during the stop-start spells of around $2 \frac{1}{2}$ years of devolved government since $1999^{1}$ the power sharing Executive 'either tended to be more conservative by instinct or allowed themselves to be conditioned by the assumptions and attitudes of civil servants' (Durkan, 2003: 1). This, he claimed, prevented a more radical government agenda. Civil servants on the other hand argued, in research commissioned to review their response to devolution, that the long standing culture and values of the civil service 'remained appropriate'. By way of contrast, politicians and external organisations considered that 'the need to develop the culture of the civil service was perhaps the biggest issue' which they faced (OFMDFM, 2002:23). Specifically, some devolved government ministers referred to inflexibility of thinking and the need for the civil service to modernize its approach

It is also clear that the Northern Ireland Civil Service has managed to evade or avoid public policy initiatives aimed at improving governance and policy making in other parts of the United Kingdom. Hence the Modernising Government agenda; Professional Policy Making for the $21^{\text {st }}$ Century; Adding it Up; and Better Policy Making, appear to have all but by-passed Northern Ireland (Cabinet Office, 1999a; Cabinet Office, 1999b; Cabinet Office 2000; and Cabinet Office, 2001, respectively). As a result, Rose's depiction in

\footnotetext{
${ }^{1}$ Until the current power sharing Assembly took office on $8^{\text {th }}$ May 2007, there had been 4 periods of devolution in Northern Ireland since the Belfast (Good Friday) Agreement: $2^{\text {nd }}$ December $1999-11^{\text {th }}$ February 2000; $30^{\text {th }}$ May $2000-10^{\text {th }}$ August 2001; $12^{\text {th }}$ August $2001-21^{\text {st }}$ September 2001; and $23^{\text {rd }}$ September $2001-14^{\text {th }}$ October 2002.
} 
1971 of Northern Ireland as 'a place apart' has been reinforced further as a kind of public administration backwater of the United Kingdom impervious to attempts aimed at improving the quality of public service provision. Instead, the Northern Ireland Civil Service has pursued what it describes as 'a reform agenda appropriate to the Northern Ireland context' outlined in a policy document entitled Fit for Purpose (OFMDFM, 2004: 8). Therein, its 'unique' reform agenda comprised 3 core elements: prioritising front line services; building capacity amongst its staff; and embracing diversity in its workforce. In practical terms, implementing the Fit for Purpose agenda is vested in the Department of Finance and Personnel which is co-ordinating a major reform programme under the banner Changing for the Better ${ }^{2}$.

Northern Ireland departments have been offered guidance on public policy through a document entitled A Practical Guide to Policy Making in Northern Ireland which makes claims to the uniqueness of devolved government and the need for policy development to be 'highly inclusive and transparent' (OFMDFM, 2003: foreword). The guide argues that 'policy decisions should be based on sound evidence' and lists internal departmental sources, government funded independent bodies, and non-government organisations as the 'likely sources of information and expertise on evidence to support policy making' (OFMDFM, 2003: 23). The policy making guide fails to acknowledge however what Williams (2002: 89) refers to as the wider political factors to which policy makers typically give weight, one of which is 'controversiality - the extent of likely support or opposition among those most affected'. Since the guide was written by civil servants primarily for a civil servant audience, straying into political territory may have been seen as outside their brief.

Yet more recent research from the Government's Social Research Unit conducted on policy making in Whitehall departments, the Scottish Executive and the Welsh Assembly, contrasts markedly with the Northern Ireland guidance by acknowledging:

\footnotetext{
${ }^{2}$ The key reforms include: the review of public administration; investment strategy for Northern Ireland; water, rating, health and education reforms; welfare modernisation; and civil service reform.
} 
The reality of policy making/delivery was described (by civil servants) as messy and unpredictable. Importantly, there was a clear understanding that evidence is just one factor to be taken into consideration alongside other factors such as the political imperative and response to media and world events (Campbell, Benita, Coates, Davies and Penn, 2007: 6).

The Social Research Unit makes reference to non-research factors which also influence policy and includes the role played by Ministers in reaching policy decisions. Some ministers, they reported, routinely ask for evidence from their officials, others were less concerned with an evidence base, or as one of the interviewees in their research put it 'there is a political context to almost everything we do... There are often political commitments that lead you in directions that the evidence doesn't necessarily strongly support' (Campbell et al, 2007: 14).

So strong is the political influence that Hope (2006) sees a basic 'incompatibility between the ideology of evidence-based policy and the natural inclination of the political process to want to secure the best outcomes' for itself (quoted in Grayson, 2006: 397). Burton has argued that the "utilisation of research-based knowledge is driven as much by political expediency and broader social and political factors as it is by standards of objective truth and epistemological certainty' (Burton, 2006: 191). He suggests policy researchers need to become more politically savvy as well as technically skilled if they are to have influence. Similarly Parsons recognises 'that 'facts' are embedded in the world of values and politics and competing frames' whereas 'evidence based policy making wishes to extricate them from the political/value quagmire' (Parsons, 2002: 58). He endorses Schön's idea that government should facilitate reflective organisations to self-transform, in contrast to the modernising agenda which is predicated on strategic steering where 'prediction and control is so difficult and 'evidence' is so problematic' (Parsons, 2002: 51). Beyond the influence of politics, Davies (2004), drawing on the work of Nutley, Walter and Davies (2003), highlights the experience, expertise and judgement of decision makers as important influences on policy making, particularly in situations where evidence is equivocal, imperfect or non-existent. Given the powerful role exerted by civil servants in Northern Ireland and the absence of a UK modernising agenda, was there an evidence based approach to public policy making? 


\section{The Review of Public Administration}

To try and understand the policy making process in Northern Ireland we examine in some detail how the (then) British Secretary of State, Peter Hain, and his ministers reached key decisions on a major public administration reform programme. In one of its earlier incarnations, the Northern Ireland Assembly decided that a pressing priority was to reform and modernise its public services. The Northern Ireland reform agenda has three main foci: investing in the infrastructure needed to deliver public services; improving public services; and a Review of Public Administration which looked at who provided services, the way they were provided, and how effectively they met the needs of the citizen (Northern Ireland Executive, 2002). At the outset, the (then) First Minister argued that the Review of Public Administration was one of the major tasks facing the Northern Ireland Executive and presented 'an opportunity of a generation to put in place a modern, accountable, effective system of public administration that can deliver a high quality set of public services to our citizens' (Trimble, 2002:371). Years of neglect and short term political 'solutions' had left the administrative landscape of public services in Northern Ireland complex and bureaucratically cumbersome. Northern Ireland was both overgoverned and over-administered, in part as a result of political intransigence and poor governance (Carmichael, 2002). With 3 MEPs, 18 MPs, 108 MLAs and 582 councillors, all for a population of 1.7 million people, it is hardly surprising that outside observers were bewildered by the extent of political representation yet little or no political progress (until recently). Equally, 11 government departments, 18 executive agencies, 5 health and social services boards, 4 education and library boards, 18 health trusts, 26 local authorities and over 100 non-departmental public bodies could only prompt the Chair of the Public Accounts Committee in Westminster to complain that 'we found again and again that the quality of governance in Northern Ireland has been below par compared to the rest of the United Kingdom' (Leigh, 2006: 253).

The Review of Public Administration was launched in June 2002 to consider 'existing arrangements for accountability, administration and delivery of public services in Northern Ireland, and to bring forward options for reform consistent with the arrangements and principles of the Belfast Agreement' (Review of Public 
Administration, 2002). Although initiated under devolved government arrangements, its stewardship by local ministers lasted just over 4 months before suspension of the Assembly in October 2002. Hence, almost the entire work of the Review was conducted through a multi-disciplinary team of officials in the Office of the Minister and Deputy First Minister, working with the advice of a group of independent experts and reporting to a direct rule British minister (Birrell, 2007). Its original timescale to produce conclusive recommendations by the end of 2003 proved overly optimistic and 'final' decisions on the outcomes were not announced by the Secretary of State until March 2006 (Office of the First Minister and Deputy First Minister, 2006). Along the way, the review team produced a comprehensive body of empirical/research work that included: attitudinal surveys; qualitative data capturing the views of users, public sector staff and key stakeholders; comparative information gathered through study visits; a mapping exercise to unravel the complexities of the public sector; and briefing papers on issues relevant to the Review. The outcomes of the Review of Administration (Better Government for Northern Ireland, 2006: 5) refer directly to the body of research outlined above 'that helped to inform these decisions'. In addition, the review team carried out two major Northern Ireland-wide public consultation exercises. The first consultation paper was published in October 2003 and attracted 174 formal responses, and the second follow-up consultation in March 2005 resulted in 1,032 responses. In short, the body of research evidence which underpinned the Review was thorough and the level of stakeholder and vested interest high, perhaps not too surprising given that the Northern Ireland economy is dominated by the public sector (with some $32 \%$ of the NI workforce employed in the public sector compared to the UK average of $22 \%$ ).

The resulting public administration reforms package announced by the Secretary of State for Northern Ireland was wide-ranging. A new Education and Skills Authority to replace a number of education bodies with direct support functions (including the 5 education and library boards); a single Health and Social Services Authority to subsume the 4 health and social services boards; 18 health trusts reduced to 5; some 81 quangos to be cut to 53; and proposals for the 26 local authorities to be reduced to 7 'super-councils'. In 
sum, the reforms when fully implemented claim to cut the number of public bodies in half from 154 to 75 , with a roll-out timetable to mid-2009.

\section{Evidence-based policy making?}

So were the final decisions of the Review of Public Administration influenced by the substantial body of evidence and research which ran in parallel with the decision making process, as the final government report claims? We consider the issue of local government reforms as an example to test this claim. Local government in Northern Ireland has since 1973 provided a limited range of public functions confined largely to recreation, leisure, street cleaning, refuse collection and certain regulatory services (e.g. building regulations and environmental health) (Birrell and Murie, 1980). Its current scale is illustrated by the fact that in 2005/06, the local government sector as a whole had a net expenditure of around $£ 360 \mathrm{~m}$, out of a budget for devolved functions of $£ 7.5$ billion, less than 5\% (Department of Finance and Personnel, 2006). Councils had been stripped of powers for their part in what Whyte (1983: 30) described as a 'consistent and irrefutable pattern of deliberate discrimination against Catholics' in electoral practices, public employment, policing, public housing and regional policy, respectively. One of the core principles of the Review of Public Administration, following years of delivering minor functions, was to deliver 'strong local government' with 'councils at the heart of the local community providing civic leadership, ensuring the provision of local services, locally delivered, and working with local interests to develop their areas' (OFMDFM, 2006: 5). Decisions on local government reforms in the Review of Public Administration included the following:

- Local councils will be reduced from 26 to 7 . The boundaries of the new councils were decided through an Independent Boundary Commissioner and are largely based on groupings of existing councils.

- The new councils will have an increased range of powers.

- Councils will have legal powers to lead a community planning process, and there will be a statutory duty on other agencies to work with the councils. In addition, councils will also have the power of 'well-being'.

- The number of councillors will be reduced from 582 councillors to 420 (7 councils by 60 councillors). 
- A system of statutory checks and balances will be developed to ensure there is fair and transparent decision-making within the new councils.

- A new system of local government finance will be developed.

The proposed timescale for implementation of the above reforms is that elections were to be held to new shadow councils in 2008 which would become fully operational in spring 2009 (a timetable now abandoned).

Did the evidence support these reforms? The most controversial decision reached by the Review was to reduce the number of councils from 26 to 7 . We consider three key elements of data gathering most relevant to the determination of the final number of councils - survey evidence, public consultation and stakeholder views. Two additional and detailed research exercises were commissioned by the Review Team to: (a) produce various council groupings which would provide for an even tax base across Northern Ireland and (b) GIS-generated administrative zones based on compactness, travel to work and population, not exceeding 300,000 (McCluskey et al, 2004; Lloyd, 2005). The former concluded that 'splitting the province into a few large areas is unlikely to produce an even tax base under either the existing or proposed rating systems' (McCluskey et al, 2004: 26). The latter claimed that 'no single set of zones is clearly 'optimal' and the most sensible approach is to detail several sets of zones which can be considered in light of other (additional) criteria' (Lloyd, 2005: 12).

During public consultation on the changes, three options were offered: 7,11 or 15 councils. The (then) Minister responsible, Lord Rooker, in announcing the Government's 'final' decisions on local government reform stated:

This morning the Secretary of State (Peter Hain) announced that all of the evidence - and I stress evidence - not opinion or speculation, pointed to seven councils as the optimum model for local government in Northern Ireland. This was a view shared by almost two-thirds of respondents to the consultation who expressed a preference (Rooker, 2005a).

This statement provided the rationale for selecting the 7 council model. We consider the various sources of evidence in some detail. 


\section{Survey evidence}

To test public opinion on proposals to reform councils, the Government's Northern Ireland Statistics and Research Agency (NISRA) conducted a probability survey between June and August 2005 of 1,148 people (from a representative sample of almost 2000 people: $59 \%$ response rate).

One of the questions posed in the survey was:

In terms of the Review's proposal to reduce the number of councils to either 7, 11 or 15, do you have a preference?

The survey findings are set out in table 1 and figure 1 .

Table 1: Preferences for Local Councils

\begin{tabular}{|l|l|l|}
\hline Answer & Percentage (\%) & Number \\
\hline Seven councils & 13 & 150 \\
\hline Eleven councils & 11 & 126 \\
\hline Fifteen councils & 27 & 310 \\
\hline No preference & 43 & 493 \\
\hline Others & 6 & 69 \\
\hline TOTAL & 100 & 1148 \\
\hline
\end{tabular}

Figure 1: How many councils?

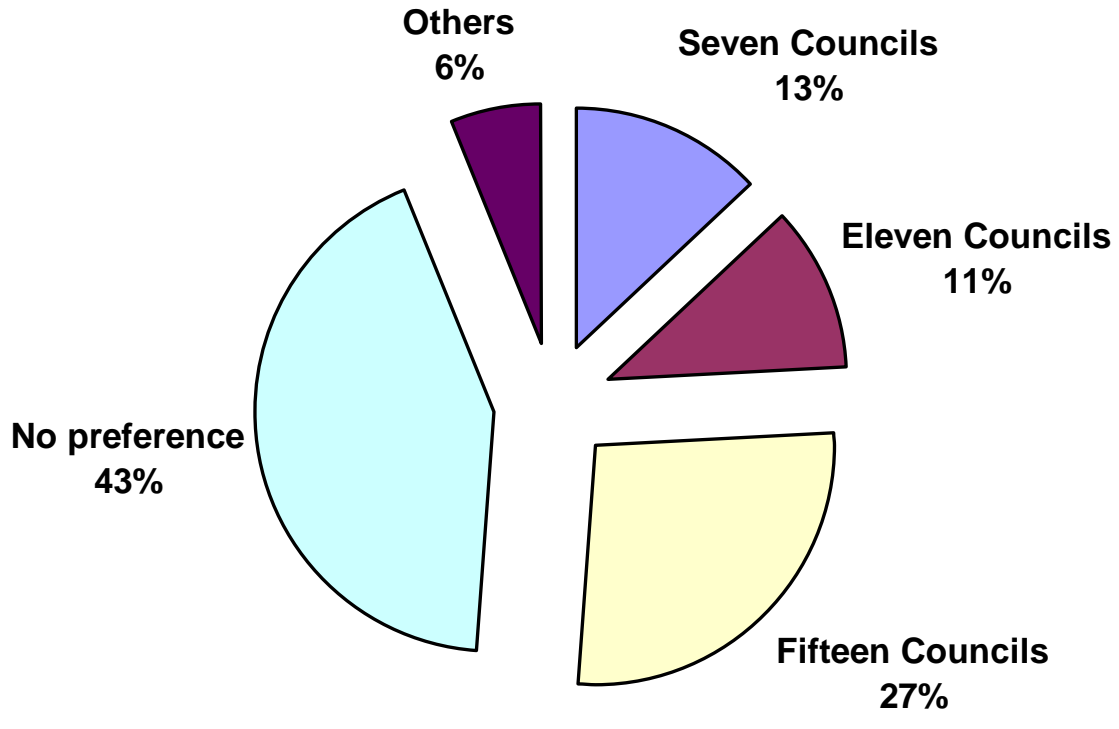




\section{$\underline{\text { Public Consultation }}$}

In addition to the above Northern-Ireland survey, evidence was provided as a result of the responses to the 'RPA: Further Consultation Document' (March 2005) which attracted 1,032 replies $^{3}$. However, the majority of these responses came from lobby campaign groups in the education sector. The non-campaign related responses amounted to 443 returns within the consultation. Some 113 consultees expressed a preference for a number or range of councils. Of these:

- 70 of the consultees expressed a preference for 7 councils (62\%)

- 80 of the consultees expressed a preference for 11 councils or less (71\%)

- 20 of the consultees expressed a preference for 15 councils (18\%)

Comparing the public consultation and survey data therefore, we can summarise the responses in table 2 .

Table 2: Public Consultation and Public Survey Evidence

\begin{tabular}{|l|l|l|l|l|}
\hline & \multicolumn{2}{|c|}{ Public Consultation } & \multicolumn{2}{c|}{ Public Survey } \\
\hline Preference & Percentage (\%) & Number & Percentage (\%) & Number \\
\hline Seven councils & 62 & 70 & 26 & 150 \\
\hline Eleven councils or less & 20 & 23 & 21 & 126 \\
\hline Fifteen councils & 18 & 20 & 53 & 310 \\
\hline TOTAL & 100 & 113 & $100 \%$ & 586 \\
\hline
\end{tabular}

The data show that Lord Rooker based his decision to reduce the number of councils to seven on the views of 70 self-selected consultees responding to the Review's further consultation document. He 'spun' the announcement by referring to evidence supporting the 7-council model from 'almost two-thirds of respondents to the consultation who expressed a preference' (in essence 70 consultees from 113). Lord Rooker failed to mention the survey data based on a random sample of people throughout Northern Ireland (data which can be extrapolated to the overall population within confidence

\footnotetext{
${ }^{3}$ The Further Consultation document secured 1032 responses but was used in a concerted campaign by the education sector to lobby around two specific reform issues - the future of: the Catholic Council for Maintained Schools (CCMS), and the youth services. Extracting the campaign-related responses $(n=589)$ resulted in 443 'usable' replies to the consultation.

${ }^{4}$ These figures discount the 'no preference' and 'others' from the survey data to make it comparable with the public consultation data.
} 
intervals) in which respondents who made their preference known overwhelmingly supported the 15 council option. Lord Rooker's successor (Minister of State David Hanson), when challenged to explain this anomaly defended his decision by claiming that respondents to the consultation paper were 'able to take a much more considered view of the issues' and, by implication, the views of a randomly selected sample of the population of Northern Ireland should be ignored - as they were (Hanson, 2007: 10). Whilst attaching weight to the opinions of some consultees, the Minister, on the other hand, chose to reject the views of key stakeholders in the local government debate, in particular the political parties. We now consider the views of the key stakeholders.

\section{$\underline{\text { Stakeholder Views }}$}

When the (then) Parliamentary Under Secretary of State, Ian Pearson, launched the second public consultation document on public administration reforms, he said:

I am grateful for the positive engagement and responses to the previous consultation document from key stakeholders, the political parties and individuals, which have helped inform the debate. I have listened carefully to the range of views expressed, in particular in relation to the future of local government (Pearson, 2005: 1).

There was widespread agreement amongst the local government sector (see responses from individual local authorities www.rpani.gov.uk) on the need for a reduction in the number of councils, with most favouring a 15 council option. On the same token, all but one of the political parties (Sinn Féin) opposed the move to 7 councils. The concerns of the four main parties, who favoured 15 councils, centred on changes to an elected forum which had remained consistently stable since 1973, and the loss of local identity. New councils would be too remote. There would be no sense of a local cohesive area, making civic leadership impossible, in areas which did not naturally perceive themselves as a community. The services returned to local authorities did not warrant the need for 7 councils, they argued, as many functions could be provided on a shared basis (Weir, 2006a: 20). The Government refused to back down on its decision to move to 7 supercouncils, provoking the following response from the President of the Northern Ireland Local Government Association (NILGA), the cross-party umbrella body representing the sector: 
I am totally shocked and dismayed that the Secretary of State, Peter Hain, has embarked on a course of action which completely undermines the opinions of the majority of elected representatives throughout the sector. NILGA is furious at the Government's decision. It is obvious that direct rule Ministers have completely ignored the legitimate voice of local politicians and proceeded with their own agenda to impose a seven council model (NILGA Press Release $22^{\text {nd }}$ November 2005a).

Most important however, there is real potential for 'balkanisation' of Northern Ireland with the proposed structural reforms to councils. The Government had produced a key policy document entitled $A$ Shared Future (OFMDFM, 2005: 11) aimed at moving the polarised Province towards a more integrated ethno-religious society described as 'sharing over separation'. Lord Rooker in outlining the final decisions of the Review of Public Administration said:

One of the key functions of councils will be to foster good community relations. The development of strong local government in Northern Ireland is a 'lightening rod' for a shared future. In future councils will ensure that good relations are earthed in the needs of local communities (Rooker, 2005b).

In fact, the proposed amalgamation of existing councils into the seven 'super councils' will accentuate community divisions as table 3 (see map 1) illustrates.

\section{Table 3: A Balkanised Northern Ireland}

\begin{tabular}{|l|c|c|c|}
\hline Proposed Council Areas & Population & Catholics & $\begin{array}{l}\text { Protestants } \\
\text { \& Others }\end{array}$ \\
\hline Cookstown,Dungannon,Fermanagh,Omagh & 185,795 & $62 \%$ & $38 \%$ \\
\hline Derry, Limavady, Magherafelt, Strabane & 215,516 & $69 \%$ & $31 \%$ \\
\hline $\begin{array}{l}\text { Armagh, Banbridge, Craigavon, Newry \& } \\
\text { Mourne }\end{array}$ & 263,384 & $55 \%$ & $45 \%$ \\
\hline Belfast & 277,391 & $47 \%$ & $53 \%$ \\
\hline $\begin{array}{l}\text { Ballymena, Ballymoney, Coleraine, Larne, } \\
\text { Moyle }\end{array}$ & 188,584 & $28 \%$ & $72 \%$ \\
\hline Antrim, Carrickfergus, Lisburn, Newtownabbey & 274,714 & $27 \%$ & $73 \%$ \\
\hline Ards, Castlereagh, Down, North Down & 279,883 & $25 \%$ & $75 \%$ \\
\hline
\end{tabular}




\section{MAP 1: THE 7 PROPOSED SUPER COUNCILS}

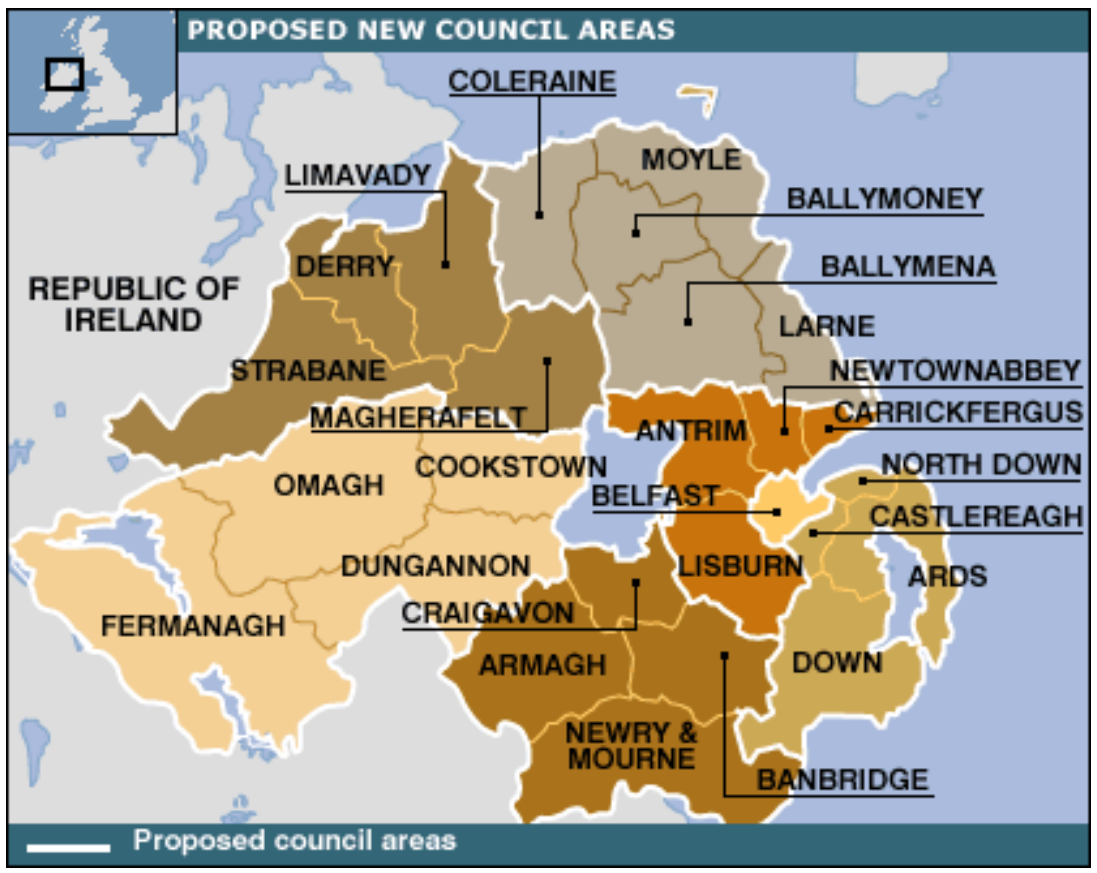

In effect, councils in the west of the Province will be nationalist/republican controlled and those in the east, Unionist dominated, with the exceptions of finely balanced Belfast City Council and the southern amalgam of local authorities. The proposals prompted (then) DUP Leader, Ian Paisley (recently retired First Minister in the new Northern Ireland Assembly) to comment 'this is a clear attempt to split the Province - nationalists will be able to develop their United Ireland policy in the councils that they dominate' (Paisley, 2005). Osborne (2007: 93), in his work on the equality agenda in Northern Ireland highlights the fact that such sectarian calculations can simply promote zero sum politics and increase tensions, but draws back from suggesting the abandonment of monitoring data along ethno-religious lines.

There was also dissatisfaction amongst stakeholders about the marginal increase in powers for local government proposed under the changes. Political parties argued that a wide range of powers should transfer from central to local government. The Northern Ireland Local Government Association (NILGA, 2005b: 3), in its response to the Review of Public Administration, 'strenuously opposed the reduction in the number of councils 
without the return of a significant level of services'. What is on offer under the Review of Public Administration is a significant reduction in the number of councils with a marginal increase in powers, perhaps a reflection of the sector's own timidity when given the opportunity to 'bid' for a much wider role in public service provision. Taking into account the new functions devolved to local government, little more than $10 \%$ of the public purse will be controlled by councils. Hardly 'strong local government' as the Government claims.

All of this seemed somewhat at odds with Ministerial contentions to be working in partnership with key stakeholders. The Review of Public Administration Further Consultation document argued:

The central assumption of the Review of Public Administration is that the new model of public administration will operate within the context of a return to devolution. On that basis, Minister Ian Pearson has worked closely with the main local political parties to ensure that they are content with the model that was being developed (Review of Public Administration Further Consultation Document, 2005b: 3.15, 27)

\section{Vested Interests}

One of the core principles of the Review of Public Administration was subsidiarity, referred to in the Better Government for Northern Ireland (2006: 5) paper as 'delivering services and exercising power as close to the people as possible'. That means, according to the Government, 'local councils having responsibility for the delivery of a wide range of services that affect the lives of people living in their areas' (OFMDFM, 2006: 5). To operationalise this principle the Review Team modelled their reforms on a two-tier system of public administration (see figure 2).

The first tier is a regional tier encompassing the Assembly, government departments, and regional authorities, the focus of which is policy development, setting standards and delivering regional services. The second tier, a sub-regional tier, encompasses organisations that operate within common boundaries to include councils, health bodies, sub-regional bodies and delivery units of regional bodies. The model assumed delivery at 
the sub-regional tier unless economies of scale (or other factors) dictated delivery on a regional basis.

Figure 2: Two-tier Model of Public Administration

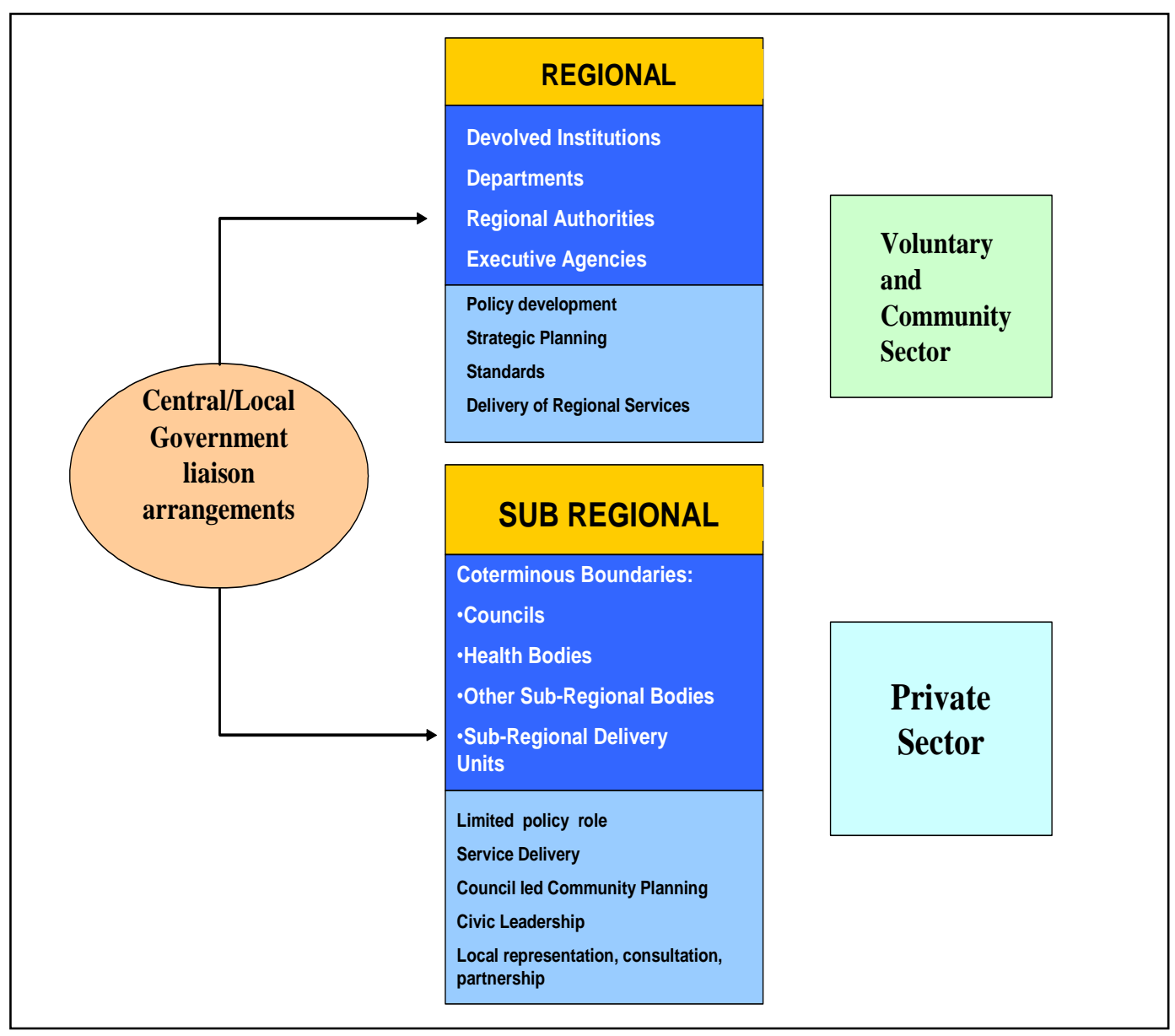

Feedback from the second consultation paper suggested there was widespread support for the two-tier model, particularly the separation in the role of central government departments, local service delivery, and an enhanced role for the voluntary and community sector. There was also backing for the transfer of the powers to local government contained in the responses to the consultation document. 'People, generally, wanted to see a more vibrant local government that would have a greater range of responsibilities and influence' (Review of Public Administration, 2005b). These qualitative responses produced as evidence from the public consultation can be confirmed by more representative quantitative data. The 2005/06 Northern Ireland Life and Times 
Survey (a probability sample of 1,200 adults aged 18 years or over) asked respondents to rank:

Which of the following have the most impact on people's everyday lives: local councils, the civil service or the Northern Ireland Assembly?

The results from the survey are set out in table 4 .

Table 4: Most Impact on People's Lives

\begin{tabular}{|l|c|c|}
\hline & Impact on people's lives & $\begin{array}{c}\text { No impact on people's } \\
\text { lives }\end{array}$ \\
\hline Local Councils & $431(36 \%)$ & $769(64 \%)$ \\
\hline Civil Service & $367(31 \%)$ & $833(69 \%)$ \\
\hline Northern Ireland Assembly & $155(13 \%)$ & $1045(87 \%)$ \\
\hline
\end{tabular}

Not surprisingly, the Northern Ireland Assembly is seen as having least impact on the lives of people. The data from the survey were collected between October 2005 to January 2006 during which the Assembly had been suspended (for the $4^{\text {th }}$ time) since October 2002. If we test the results ( 2 related dichotomous variables) there is a significant difference in people's attitudes to these institutions (Cochran's Q (2) $=175.6$, $\mathrm{p}<.05)$. What these data confirm is that the role played by local councils in Northern Ireland is far beyond their limited functional responsibilities - councillors are the first point of contact for people having problems with public services. Moreover, the data also highlight the democratic deficit in the absence of a functioning Assembly (at that time) and the power base of civil servants under direct rule government - the civil service was perceived as highly influential by the public.

Consistent with the regional/local subsidiary model and the empirical evidence on the impact of local government, NILGA strenuously opposed any reduction in the number of councils without the return of core public services. NILGA argued that local government should be of sufficient size and significance to be a partner with central government and provide an effective balance of power (NILGA, 2005b). As the new devolved Assembly commenced business (May 2007), the central-local partnership concept based on the principle of subsidiary is a myth. Key public services are still vested in the hands of powerful civil servants with a centralised public administration system across 11 
government departments, untouched by the Review of Public Administration. This suggests that there is no power-dependent relationship between central and local government in Northern Ireland (Rhodes, 1986). The contrast with devolved government in Scotland and Wales is striking here (Laffin, Taylor \& Thomas, 2002; Bennett, Fairley and McAteer, 2002; McAteer \& Bennett, 2005; McConnell, 2006). The Welsh Assembly sees local government as crucial in delivering effective public services. As Laffin (2004: $216 \& 220$ ) puts it 'for them (the Welsh Assembly) local government forms a vital implementation structure which absorbs about a third of the Assembly budget' and the Welsh Assembly is 'considerably more dependent on local government than central government is on English local government; and a similar argument can be advanced in Scotland'. Compare this to councils in Northern Ireland which deliver minor functions in waste collection, environmental health and leisure services accounting (at present) for less than $5 \%$ of public expenditure. In this sense Northern Ireland is more like England which is characterised by asymmetric central-local relations in favour of the centre. Devolved regional government in Northern Ireland has not resulted in regional centralism (where powers became more centralised at Stormont), rather it has simply reinforced the status quo of asymmetric relations with a strong centre and locally elected ministers reluctant to transfer functions to councils. Here again, the contrast with other parts of the United Kingdom is plain. Laffin (2007) argues that devolution does not inevitably lead to regional centralism particularly where a power balance or symmetry exists between regional and local governments, as in the case of Wales and Scotland. Yet in Northern Ireland regional centralism pre-dates devolution and is rooted in the abuse of power by local government which, in part, sparked the civil rights marches and 'troubles' in the late 1960s. With the emergence of devolution in 1999 and the lust for political power, largely denied for over 25 years, Members of the Northern Ireland Legislative Assembly did not feel inclined towards strengthening the role of local government.

The degree of central government insulation from the wider UK reform process is also illustrated by the exclusion of the Northern Ireland civil service from capability reviews conducted on Westminster departments (independent assessments of how departments 
are performing). The former Chair of the Northern Ireland Assembly's Public Accounts Committee (Billy Bell) commented:

The Northern Ireland departments have already evaded inspection under the Review of Public Administration. To my mind, that was quite wrong - I never understood how a comprehensive review of public administration could be carried out in Northern Ireland which excluded civil service departments and confined itself only to councils and health and education boards. Many people in the councils and boards feel very aggrieved that they should be subject to a major review, facing a very uncertain job future, while the civil servants in the departments get off scot-free (Bell, 2005:1).

There is however substantial evidence of the need for reforms to both the structure and effectiveness of central government departments in Northern Ireland. Parry's work (2003) on the issues facing the civil service in Scotland under devolution is equally significant in Northern Ireland. He described four challenges facing Scottish civil servants: how they present themselves and relate to others; how they configure and operate the administrative machine; how they see themselves relating to the traditions of the Civil Service; and how they equip themselves to advise ministers on policy development. Former Minister Lord Rooker, for example, described the structure of 11 NI departments as 'absolutely bamy'. During his time as a direct rule minister in Northern Ireland with line responsibility for four departments he said, 'let's face it, the structure of 11 departments is illogical. Every week I find I am responsible for something new. The structure was created after the Good Friday Agreement to ensure there were enough ministerial portfolios to share between parties' (Rooker, 2005c:1). Yet performance by civil service departments has attracted severe criticism from Westminster's Public Accounts Committee. One member noted 'I am worried that Northern Ireland's citizens and taxpayers may not be receiving the service we expect to see in the rest of the United Kingdom. The overall message must be, in all the areas that we have looked at, there is enormous scope to improve' (Bacon, 2006: 11). 


\section{Conclusions}

So why would (direct rule) ministers choose to ignore empirical evidence in reaching decisions about public administration reform in Northern Ireland? Were there wider political issues at stake? The position of Sinn Féin on local government reform is instructive. All political parties resolutely opposed the reduction in the numbers of councils from 26 to 7, except Sinn Féin. The obvious question is why was Sinn Féin supportive of direct rule ministers on this issue? This is all the more intriguing when one of its senior members (Francie Molloy), who held the post of vice-president of the Northern Ireland Local Government Association, was suspended by Sinn Féin in November 2005 for contravening party policy and adopting NILGA's position in favour of 15 councils.

Two issues arise from the seemingly apolitical public services reform agenda. First, the political demography of the seven-council model may well allow Sinn Féin to gain control of sizeable areas west of the Province, in keeping with accusations from the DUP that this is an insidious threat to move the Donegal, Leitrim, Cavan and Monaghan borders and expand the Republic of Ireland. Second, the controversial nature of the public administration reform agenda was to goad the political parties into responding positively to a power-sharing executive and the restoration of devolution. This was captured by one Minister's informal remark 'if you don't like it, you know what to do', a clear reference to local representatives participating in devolved government. In a debate in the transitional Assembly, one DUP representative voiced concerns about government tactics:

The Government has constantly blocked debate on the Review of Public Administration issue because the decision to support a seven-council model is one of the least justifiable of their many bad recent decisions. It has the least merit, is the most politically driven and has been produced for the wrong reasons. It is particularly appalling that the Government has used the issues of reform of public administration and the number of councils as devices in its wider schemes for political progress in Northern Ireland (Weir, 2006b).

As a result of this debate, the transitional Assembly expressed serious disquiet about the potential of a 7 council model to centralise services, remove jobs and resources from 
many areas, and to underpin sectarianism and community division; and called on the Secretary of State 'to shelve present plans for super councils and allow the decision on future council arrangements to be taken by a restored Northern Ireland Assembly' (Hansard, $5^{\text {th }}$ December 2006).

The reforms arising from the Review of Public Administration were described as 'a vision of change that represents the greatest single challenge to the public sector in Northern Ireland for over 30 years' (Hain, 2005: 14). From our analysis it is clear that key empirical evidence in reaching decisions on the potential reform package was ignored. Should we be surprised by this? Young, Ashby, Boaz and Grayson (2002) contrast the ideal type policy process and the realities of policy making in the following way. In the former, 'information is supplied which is objective, and possibly conclusive, reducing uncertainties about the relationship between policies and outcomes'. In the latter, 'decisions are less about projected consequences and more about process and legitimation. Politics is about shaping interpretations and expressing preferences' (Young et al, 2002: 218). In fact, the Northern Ireland case study is a good example of Young et al's 'political/tactical' model in which policy is an outcome of the wider political process (in this case, forcing local politicians to share power). Their warning (Young et al, 2002: 217) that in extreme cases the research/researcher can become vulnerable to political attack' transpired. Minister Hanson, somewhat ironically, attacked the evidence presented by this author as being 'selective in the information chosen' and 'not providing alternative research in support of another council model' (Hanson, 2007:10).

The Review of Public Administration accumulated a significant body of evidence to support the final decisions arrived at by the Secretary of State. Expecting the outcomes to be causally linked to the evidence is to ignore the messy realities of the decision making process in Northern Ireland and elsewhere. Civil servants, with their monopoly on power, and largely unaffected by the wider UK modernising agenda which promoted the primacy of evidence based policy making, drove the reform agenda. A hand-picked team of officials conducted the review of public administration and, by design, the process excluded government departments. In 'normal' direct rule circumstances the will of 
senior civil servants would have prevailed. But a bigger political prize was at stake. Direct rule ministers sought to provoke locally elected representatives and their political parties into agreeing to devolution by deliberately opposing their views on the reforms of local government. Local government reform in Northern Ireland is perhaps an unintended example of the kind of process referred to by Parsons (2002: 56) who, drawing on the work of Lasswell, argued that the aim of policy sciences is to contribute to the democratisation of the policy making process, in contrast to an evidence based approach which seeks 'to de-politicise and managerialise knowledge production and its utilisation'.

With the return to a devolved administration in Northern Ireland, local government reform is back on the policy agenda and the new Assembly reviewed 'final' decisions by their direct rule predecessors to set up 7 'super-councils'. Local Department of Environment Minister, Arlene Foster, launched 'a review of the review' in August 2007 and subsequently overturned both the number and functions of local government agreed in the Review of Public Administration. The instrumental rationality synonymous with evidence based policy was eschewed by direct rule ministers in favour of political decision making and locally elected ministers followed suit. Despite hostility from the local government community, Minister Foster announced to the Northern Ireland Assembly (31 ${ }^{\text {st }}$ March 2008) that:

- The number of councils in Northern Ireland will now be rationalised from 26 to 11.

- Additional functions of the new councils will include: local development plans; local public realm aspects of roads; urban regeneration and community development; housing-related functions; local economic development; and local tourism, arts, sports and leisure.

- An independent Local Government Boundaries Commissioner was appointed (for the second time) to redraw 11 new council boundaries.

- A local government modernisation process will be supported by the Department of the Environment.

- The timeline for reorganised local government will now be elections to the new councils in 2011.

The new functions will require a $25 \%$ increase in council budgets and $12 \%$ increase in council staffing. This suggests an annual (new) council expenditure of around $£ 575 \mathrm{~m}$ out of a total devolved budget of around $£ 8$ billion - just over $7 \%$ of the public purse. 
Councils have been offered public realm roads responsibilities such as weed spraying and emptying gullies, hardly the stuff of 'strong local government' promised at the outset of the Review of Public Administration. Local government will remain for the foreseeable future a relatively minor player in the governance arrangements of Northern Ireland. The asymmetry of power relationships between Stormont and councils has not shifted as a result of devolution. Instead, there has been a marginal increase in the functions of local government and a Policy Development Panel, comprising councillors and local government officers, established to develop central-local relations under the new 11council arrangements. The Policy Development Panel will report to a Strategic Leadership Board set up to oversee the transition process until 2011 and chaired by the Minister of the Environment. Drawing on the Welsh model, current proposals are to establish a statutory Partnership Panel comprising joint membership from the Northern Ireland Executive and local government elected representatives. In practice, given the lack of power dependence between the central and local government, it is difficult to see this as anything other than a mechanism for communication, consultation and advice.

In summary, the decisions on the reform of local government in Northern Ireland were always going to be politically determined. This paper sought to test the robustness of the Minister's claim that they were otherwise. Devolution and the Review of Public Administration have not provided the opportunities to strengthen the role of local government in Northern Ireland. Instead, the asymmetry of power relationships between central and local government has been reinforced, aided and abetted by a powerful civil service unwilling to see their departments dismantled and functions devolved to councils. The political outworkings of the Belfast (Good Friday) Agreement, in which political parties are keen to demonstrate their ministerial credentials, has compounded these centripetal tendencies. Regional centralism and limited local government best characterise Northern Ireland's governance arrangements now and in the future. 


\section{References}

Bacon, R. (2006) 'A PAC Member's perspective on service delivery and accountability' Speech to the Chartered Institute of Public Finance in Northern Ireland, 23 March.

Bell, W. (2005) ‘Anger Over Civil Service Review’ Belfast Telegraph, $21^{\text {st }}$ October.

Bennett, M., Fairley, J. and McAteer, M. (2002) Devolution in Scotland: The Impact on Local Government. York: Joseph Rowntree Foundation, York Publishing Services

Birrell, D. and Murie, A. (1980) Policy and Government in Northern Ireland: Lessons of Devolution. Dublin: Gill and Macmillan.

Birrell, D. (2007) 'The role of local government in the review of public administration in Northern Ireland: The challenges of enhancement, devolution and modernization', Local Government Studies, 33 (5): 657 - 676.

Burton, P. (2006) 'Modernising the Policy Process: making policy research more significant?', Policy Studies, 27 (3): 173 - 195.

Cabinet Office (1999a) Modernising Government. White Paper. Cm 4310. London: HMSO.

Cabinet Office (1999b) Professional Policy Making for the $21^{\text {st }}$ Century. A report by the Strategic Policy Making Team. London: HMSO.

Cabinet Office (2000) Adding it Up: Improving analysis and modelling in Central Government. A Performance and Innovation Unit Report. London: HMSO.

Cabinet Office (2001) Better Policy Making, Centre for Management and Policy Studies. London: Cabinet Office.

Campbell, S., Benita, S., Coates, E., Davies, P. and Penn, G. (2007) Analysis for Policy: evidence-based policy and practice. London: HM Treasury, Government Social Research Unit.

Carmichael, P. (2002) 'British Governance in Transition: A Case Study of the Northern Ireland Civil Service', International Journal of Public Administration, 25 (8), 975-1005.

Carmichael, P. (2002) 'The Northern Ireland Civil Service: Characteristics and Trends since 1970', Public Administration, 80 (1), 23-49.

Davies, P. (2004) 'Is Evidence-Based Government Possible?' Jerry Lee Lecture - paper presented at Campbell Collaboration Colloquium: Washington DC. 
Department of Finance and Personnel (2006) Northern Ireland Priorities and Budget 2006-08. Belfast: DFP.

Durkan, M. (2003) 'Durkan takes a swipe at civil servants' Belfast Telegraph, $31^{\text {st }}$ October: 1 .

Grayson, L. (2006) ‘Revitalising Analysis for Policy’, Evidence and Policy, 2 (3): 397 399.

Hain, P. (2005) Statement by the Secretary of State for Northern Ireland on the Outcome of the Review of Public Administration. Belfast: Northern Ireland Office, $22^{\text {nd }}$ November.

Hain, P. (2007) Northern Ireland. Statement to the House of Commons, $9^{\text {th }}$ May.

Hansard (2006) The Review of Public Administration' Northern Ireland Transitional Assembly debate, $5^{\text {th }}$ December.

Hanson, D. (2007) 'The Review of Public Administration: The Minister replies' Fortnight Magazine No. 450: 10 - 11.

Hope, T. (2006) ‘Things can only get better’, Criminal Justice Matters, 62 (39): 4 -5.

Laffin, M., Taylor, G. and Thomas, A. (2002) A New Partnership? The National Assembly for Wales and Local Government. York: Joseph Rowntree Foundation, York Publishing Services.

Laffin, M. (2004) 'Is Regional Centralism Inevitable? The Case of the Welsh Assembly' Regional Studies 38(2): 213-223.

Laffin. M. (2007) 'Comparative British Central-Local Relations: Regional Centralism, Governance and Intergovernmental Relations' Public Policy and Administration 22(1): 74-91.

Leigh, E. (2006) 'Northern Ireland' Hansard, 243-277 Public Accounts Committee, $18^{\text {th }}$ July.

Lloyd, C. (2005) Identification of New Administrative Zones using Districts as a Base. Belfast: The Queen's University.

McAteer, M. and Bennett, M. (2005) 'Devolution and Local Government: Evidence from Scotland' Local Government Studies 31 (3): 285 - 306.

McCluskey, W., Lim, J. and Davis, P. (2004) Review of Public Administration in Northern Ireland: Main Research Findings. Report No. 3. Belfast: OFMDFM. 
McConnell, A. (2006) Central Local Government in Scotland, International Review of Administrative Sciences 72 (1): 73-84.

Northern Ireland Executive (2002) Draft Programme for Government. Belfast: Office of the First Minister and Deputy First Minister.

Northern Ireland Local Government Association (2005a) 'Demolishing Democracy for Efficiency - NILGA slams RPA announcement'. NILGA Press Release $22^{\text {nd }}$ November.

Northern Ireland Local Government Association (2005b) NILGA's Response to the RPA Further Consultation Paper. Belfast: NILGA

Northern Ireland Research and Library Services (2001) Freedom of Information Research Paper 10/01. Stormont: Northern Ireland Assembly.

Nutley, S., Walter, I. and Davies. H. (2003) 'From Knowing to Doing: A framework for understanding the evidence-into-practice agenda' Evaluation, 9 (2): 125 - 148.

Office of the First Minister and Deputy First Minister (2002) Review of the Northern Ireland Civil Service Response to Devolution. Belfast: OFMDFM.

Office of the First Minister and Deputy First Minister (2003) A Practical Guide to Policy Making in Northern Ireland. Belfast: OFMDFM.

Office of the First Minister and Deputy First Minister (2004) 'Fit for Purpose' The Reform Agenda in the Northern Ireland Civil Service. Belfast: OFMDFM.

Office of the First Minister and Deputy First Minister (2005) A Shared Future: Policy and Strategic Framework for Good Relations in Northern Ireland. Belfast: OFM\&DFM.

Office of the First Minister and Deputy First Minister (2006) Better Government for Northern Ireland: final decisions of the review of public administration. Belfast: OFM\&DFM.

Osborne, R. (2007) 'Evidence' and equality in Northern Ireland', Evidence and Policy, 3 (1): $79-97$.

Paisley, I. (2005) 'Reaction to local government shake-up' BBC News report $22^{\text {nd }}$ November.

Parry, R. (2003) 'The Scottish Executive and the Challenges of Complex Policy-Making' The Political Quarterly 74 (4): 450-458.

Parsons, W. (2002) 'From muddling through to muddling up: evidence based policy making and the modernisation of British Government', Public Policy and Administration. 17 (3): $43-60$. 
Pearson, I. (2005) The Review of Public Administration in Northern Ireland: Further Consultation. Belfast: RPA.

Review of Public Administration (2002) Terms of Reference and Parameters for the Review http://www.rpani.gov.uk/tor.htm

Review of Public Administration Further Consultation Document (2005a). Belfast: RPA.

Review of Public Administration (2005b) Analysis of responses to the 'Further Consultation'. Belfast: RPA.

Rhodes, R. (1986) The National World of Local Government. London: Allen \& Unwin

Rooker, J. (2005a) 'Outcome of the Review of Public Administration' speech by Lord Rooker at the Northern Ireland Commissioner for Children and Young People, $22^{\text {nd }}$ November 2005.

Rooker, J. (2005b) 'Rooker heralds the return of strong local government'. RPA Press Release $22^{\text {nd }}$ November.

Rooker, J. (2005c) 'Minister Rooker slams 'bamy' Ulster' Belfast Telegraph, $18^{\text {th }}$ August.

Rose, R. (1971) Governing without Consensus: An Irish Perspective. London: Faber.

Simpson, J. (1997) 'Yes, Minister that would have to be my decision' Belfast Telegraph, April $22^{\text {nd }}: 4$.

Trimble, D. (2002) 'Review of Public Administration' Hansard 371 - 402, $25^{\text {th }}$ February. Belfast: Northern Ireland Assembly.

Weir, P. (2006a) 'Positive about reforms but on local government terms!!' Direct News, December 2005 - January 2006: 20-21.

Weir, P. (2006b) 'The Review of Public Administration' Hansard Northern Ireland Transitional Assembly debate, $5^{\text {th }}$ December.

Whyte, J. (1983) "How much discrimination was there under the Unionist regime 192168?" in T. Gallagher and J. O'Connell (eds) Comtemporary Irish Studies. Manchester: Manchester University Press.

Williams, N. (2002) 'Evidence and Policy: towards a new politico-administrative settlement' Political Quarterly. 73(1): 86-102 
Young, K., Ashby, D., Boaz, A. and Grayson, L. (2002) 'Social science and the evidencebased policy movement', Social Policy and Society 1 (3): 215 - 224. 